\title{
MANAGEMENT CONTROL SYSTEMS IN MADEIRA ISLAND LARGEST FIRMS: EVIDENCE ON THE BALANCED SCORECARD USAGE
}

\author{
Carla Curado $^{1}$, José Manica² \\ 1,2ISEG - Technical University of Lisbon, Rua Miguel Lupi, 20, 1249-078 Lisbon, Portugal \\ E-mails: ${ }^{1}$ ccurado@iseg.utl.pt (corresponding author); ${ }^{2}$ josemanica@hotmail.com
}

Received 23 December 2009; accepted 24 September 2010

\begin{abstract}
This paper describes the findings of an exploratory study on the use of management control systems in Madeira Island providing evidence on the Balanced Scorecard (BSC) usage. Empirical data collected illustrates the degree of BSC usage at the Island's biggest corporations and provides response to the research questions. The findings reveal remarkable differences concerning management control systems' use across corporations in the study and previous research reports from other regions. Finally, this study discusses managerial implications and includes invitations to future research directions.
\end{abstract}

Keywords: management control systems, balanced scorecard, large firms, empirical study.

Reference to this paper should be made as follows: Curado, C.; Manica, J. 2010. Management Control Systems in Madeira Island Largest Firms: Evidence on the Balanced Scorecard Usage, Journal of Business Economics and Management 11(4): 652-670.

\section{Introduction}

Information access and use allows for a more correct decision making, following organizational strategic goals (Cadez and Guilding 2008). Information systems support strategic control and decision making. Evaluation and measurement systems are among the most commonly employed organizational information systems managers make use of (Neely and Al Najjar 2006), their main function is to give managers a control tool. Information systems quality and composition present clear evolution over the last decades. Since the 80's academic literature and recommendations from practitioners suggests the use of non financial indicators as powerful instruments to assist organizational management (Malina and Selto 2001). Pun and White (2005) offer the evolution of performance management systems, which reflects the different kinds of management information systems characteristics managers have available. Traditional performance management systems are based on costs and efficiency indicators, they stand on data from the traditional accounting systems. Short-term and profit orientation are highly valued in these systems. The prevalence of individual and functional measures along with the comparison with standards set the tone. Emerging performance management systems on the contrary are based on company strategy and performance compatibility, 
they are value-based. Long term and customer orientation are highly valued in these systems. The prevalence of team and transversal measures enable continuous improving monitoring. Traditional management information systems essentially present a financial substance (Kaplan and Norton 1996a). The quality and adequacy of such information alone is questioned in literature and deficiencies allegedly affect them. Table 1 provides a list of deficiencies in traditional systems from relevant literature review.

Table 1. Deficiencies in traditional systems

\begin{tabular}{ll}
\hline Traditional systems & Authors in literature \\
\hline Emphasize short-term financial performance & Fu et al. (2008); Kaplan and Norton (1996a); \\
& Ittner and Larcker (1998); Bourguignon et al. \\
& (2004); Neely and Al Najjar (2006); Malina \\
& and Selto (2001)
\end{tabular}

Fail to match long term strategy to short term actions
Fu et al. (2008); Ittner and Larcker (1998); Bourguignon et al.(2004); Malina and Selto (2001)

Create a gap between strategic formulation and implementation Bourguignon et al. (2004)
Fail to reflect organizational continuous improvements and innovation

Only allow for an historic approach to organizational performance

Aren't able to identify the organizational value creating activities

Don't consider some important intangible assets

Don't allow managers to verify if the firm is attaining strategic goals

Don't give information enough to correctly assess managers' performance, apart from short-term financial indictors

Present little information on causes and solutions to organizational problems

identify key changes in the business far too late

Reflect organizational functions structure and not multi-functional processes

Present information that is too much aggregated and summarized

Aren't useful when adopting other tools like TQM that require information on the Consumer's satisfaction
Fu et al. (2008); Kaplan and Norton (1996a);

Kaplan and Norton (1992); Malina and Selto (2001)

Kaplan and Norton (1992); Ittner and Larcker (1998)

Kaplan and Norton (1992); Neely and Al Najjar (2006)

Kaplan and Norton (1996a); Ittner and Larcker (1998); Malina and Selto (2001)

Kaplan and Norton (1996b); Ittner and Larcker (1998)

Sliwka (2002); Ittner and Larcker (1998)

Ittner and Larcker (1998)

Ittner and Larcker (1998)

Ittner and Larcker (1998)

Ittner and Larcker (1998)

DeBusk et al. (2003); Ittner and Larcker (1998); Malina and Selto (2001) 
Traditional management information systems imperfections led to an organizational search for more suitable systems and forcing to improve previous ones. Traditional management information systems solely based upon financial indicators suffered great changes, developing into more complete ones and presenting a strategic role (Cadez and Guilding 2008; Malina and Selto 2001; Sioncke and Parmentier 2007). Strategic management benefits from the use of emerging systems that allow decision makers to access more quality and critical information (Kaplan and Norton 2005, 2008). Table 2 presents a catalog of emerging systems.

Table 2. Emerging systems

Strategic Management Analysis and Reporting Technique (SMART)

Performance Measurement Questionnaire (PMQ)

Results and Determinants Matrix (R\&DM)

The Balanced Scorecard (BSC)

Comparative Business Scorecard (CBS)

Cambridge Performance Measurement Process (CPMP)

Consistent Performance Measurement Systems (CPMS)

Integrated Performance Measurement Systems (IPMS)

Dynamic Performance Measurement Systems (DPMS)

Integrated Performance Measurement Framework (IPMF)

Source: Adapted from Pun and White (2005).

Strategic management information systems do not eliminate the need for traditional ones, on the contrary, they complement them, allowing for managers to make their decisions based upon financial as well as non financial indicators (Kaplan and Norton 1992; Ittner and Larcker 1998). Financial indicators got improved over time leading to current ones like EVA, ${ }^{\circledR}$ - Economic Value Added, or CFROI - Cash Flow Return on Investment, that focus on the organizational need to create value (Ittner and Larcker 1998; DeBusk et al. 2003). Non financial indicators include consumer and employees satisfaction indexes or quality ratios, which focus on controlling now to guarantee long term organizational survival (Ittner and Larcker 1998). The use of both, financial and non financial, indicators will support and facilitate the decision making process and the organizational performance appraisal. In addition, the combined use of them captures the present value of the firm in a more comprehensive way and allows for the depiction of the business value creation factors that may ensure future organizational success (Ittner and Larcker 1998). Adopting non financial indicators enlightens the causes over the results, enabling managers to predict future organizational performances Wiersma (2008). The BSC is among fresh strategic management information systems sharing many similarities with the predecessor Tableax de Bord, and easier to implement Bourguignon et al. (2004). Both systems convert organizational strategy and vision in goals and associated indicators, emphasizing proactive moves over reactions and enabling top management decision to match employees’ actions. 


\section{Theoretical justifications and limitations of management control systems}

The BSC is used to monitor, implement and share strategy throughout all the organization (Collis and Rukstad 2008). Strategic goals break down into operational ones through delegation setting the pathway to daily work, enabling strategy implementation (Kaplan and Norton 1996a; Epstein and Manzoni 1998). The BSC is not Besides being a strategic control instrument, the BSC is a communicational tool and serves planning (Valentinavičius 2009) by presenting lagging and leading performance measures (Kaplan and Norton 1996a). The financial (lagging) indicators reveal the results of past decisions and actions (Epstein and Manzoni 1998). The non financial (leading) indicators (Malina and Selto 2001) - related to clients; internal processes and learning and growth - reveal how the firm is working and preparing its future. The four sets of indicators are equally relevant (Hoque and James 2000; DeBusk et al. 2003; Pun and White 2005; Kaplan and Norton 2008) and much in need to achieve organizational success and long term survival. The BSC helps managers in the strategy creating process as well as in the succeeding effective communication effort. The usefulness of the management information systems is intimately related to the indicators choice and the relevancy given to contextual variable (Epstein and Manzoni 1998; Veen-Dirks and Wijn 2002).

In practice the BSC is often materialized into an 18 to 25 indicators set, comparing organizational performance against planned targets. The application of the BSC does not involve the use of plenty indicators, but just half a dozen key strategic ones that enable managers to clearly identify cause and effect relations (Hoque and James 2000). Adopting indicators from several areas minimizes risk involved in decision making (Ittner and Larcker 1998), by having two streams of indicators; on the one hand lag, financial, internal performance focused and short-term goals oriented, and on the other hand, lead, non financial, external performance focused and long-term goals oriented (Walker and Ainsworth 2007; Mooraj et al. 1999). The fact that sort term financial indicators present good figures does not guarantee organizational health, or successful strategic implementation (Kaplan and Norton 1996a) only the use of both financial and non financial indicators can help managers sustaining future performance (Fu et al. 2008).

\section{Conceptual underpinnings and literature linkages on the BSC}

The BSC concept emerges to fill the gaps of inadequacy traditional management information systems present for measuring strategic performance (Nørreklit 2000, 2003), since financial indicators are no longer sufficient to support management (Walker and Ainsworth 2007). Firms became highly complex, client focused and human capital dependent (Lobanova 2009), basing their performance mainly on intangible assets (Ittner 2008). Kaplan and Norton's (1992) revolutionary article at the Harvard Business Review led to several interpretations of the BSC. Several recent interpretations of the BSC are listed in Table 3.

Three types of BSC concepts reflect the different stages of evolution that this management information system went through, since Kaplan and Norton's introduction (Speckbacher et al. 2003): 
Type 1 BSC - The 1992 Kaplan and Norton's concept presenting a multidimensional framework combining financial and non financial indicators that illustrate organizational vision and strategy.

Type 2 BSC - A representation that includes Type 1 BSC plus a description of strategy on a basis of cause and effect relationship between the different sets of indicators. Learning (Kumpikaite 2008) and growth indicators have impact on internal processes and these will influence clients' indicators. In the end of this cause and effect chain the financial indicators will reflect the result of all previous activity in the firm, therefore the need for both lead and lag indicators in the BSC is imperative (Bourguignon et al. 2004) for the organizational moves into the future shouldn't depend purely upon financial indicators (Nørreklit 2003).

Type 3 BSC - A version that includes Type 2 BSC plus an integrated structure to serve strategy implementation, defining organizational goals, plans, results and incentives (Kaplan and Norton 1996a, b). Type 3 BSC is a true strategic management system connecting strategic objectives to operational activities allowing for strategic learning. This most developed concept of BSC emphasizes its usefulness in the strategic implementation process over the strategic formulation phase (Veen-Dirks and Wijn 2002).

The BSC concept attracted the attention of several authors over the years and new models arouse inspired by the initial idea. The Aligned Balanced Scorecard (ABS) aims to overcome some of the Kaplan and Norton's BSC limitations (Thompson and Mathys

Table 3. BSC interpretations

\begin{tabular}{ll}
\hline BSC consists of & Authors in literature \\
\hline $\begin{array}{l}\text { Strategic communication device and management control } \\
\text { instrument }\end{array}$ & Malina and Selto (2001) \\
\hline Innovative tool for managers & Nørreklit (2003) \\
\hline $\begin{array}{l}\text { Organizational competitive advantage improvement tool } \\
\text { presenting a broader assessment }\end{array}$ & Lusk et al. (2006) \\
\hline Accountancy figure innovation & Ax and Bjørnenak (2005) \\
\hline Management control instrument & $\begin{array}{l}\text { Lipe and Salterio (2002); } \\
\text { Nørreklit (2003) }\end{array}$ \\
\hline Manager's structured thinking system & Veen-Dirks and Wijn (2002) \\
\hline $\begin{array}{l}\text { Innovative system integrating financial and non financial } \\
\text { indicators }\end{array}$ & Ittner and Larcker (1998) \\
\hline $\begin{array}{l}\text { Framework for strategic measuring using operational and } \\
\text { financial indicators }\end{array}$ & Pun and White (2005) \\
\hline Organizational performance analysis tool & Islam and Kellermanns (2006) \\
\hline $\begin{array}{l}\text { Guide to strategic development, implementation and } \\
\text { communication }\end{array}$ & Islam and Kellermanns (2006) \\
\hline The most significant development in business accounting & Malina and Selto (2001) \\
\hline
\end{tabular}


2008). The ABS illustrates how internal operations occur and presents causal alignment of events connecting internal processes indicators to client ones and to financial results, consequently this tool reinforces the relevancy of choosing the correct indicators for each area. Using this framework proves valuable to identify how organizational strategy clearly influences learning and growth alternatives towards internal processes improvement. The ABS main distinction from the BSC is the dynamic aspect of proposing an organizational chain linkage of activities to support strategy. Subsequent to the successive ascending impacts among the four BSC levels resulting in the accomplishment of organizational goals, the ABS suggests a feed-back move where strategic plans are translated into action plans for learning and growth activities (Thompson and Mathys 2008).

\section{Advantages and disadvantages in the use of the BSC}

Regarding the BSC do the benefits compensate for the associated costs? This is a complex question and not straightforward to answer Mooraj et al. (1999). The BSC use legitimacy depends on the improvements its employ generates in the management decision making, so that results recompense the usage of this expensive system (Lipe and Saltério 2000). Literature presents arguments for (see Table 4) and against (see Table 5) the BSC use, but the former surpass the latter.

Table 4. BSC Advantages

\begin{tabular}{|c|c|}
\hline Advantages & Authors in literature \\
\hline Aligns strategic goals to actions taken & Speckbacher et al. (2003) \\
\hline $\begin{array}{l}\text { Allows a fast and precise observation of } \\
\text { business, visualizing performance coming } \\
\text { from several perspectives }\end{array}$ & $\begin{array}{l}\text { Kaplan and Norton (1992);Wong-On-Wing } \\
\text { et al. (2007); Epstein and Manzoni (1998); } \\
\text { Malina and Selto (2001) }\end{array}$ \\
\hline $\begin{array}{l}\text { Facilitates communication between } \\
\text { organizational levels by articulating goals, } \\
\text { values and beliefs, reinforcing culture and } \\
\text { driving behaviour }\end{array}$ & $\begin{array}{l}\text { Epstein and Manzoni (1998); Islam and } \\
\text { Kellermanns (2006) }\end{array}$ \\
\hline $\begin{array}{l}\text { Connects multiple sorts of non financial } \\
\text { indicators (performance drivers) to financial } \\
\text { indicators (final results metrics) }\end{array}$ & Wong-On-Wing et al. (2007) \\
\hline $\begin{array}{l}\text { Avoids information overload by limiting the } \\
\text { number of variables and focusing on the most } \\
\text { relevant indicators }\end{array}$ & DeBusk et al. (2003) \\
\hline $\begin{array}{l}\text { Enables the materialization of vision and } \\
\text { strategy by an easy use tool }\end{array}$ & Ittner and Larcker (1998) \\
\hline Easy to apply & Kanji and Moura de Sá (2002) \\
\hline $\begin{array}{l}\text { Allows clarification, consensus and focusing } \\
\text { on performance improvement needs }\end{array}$ & Kaplan and Norton (1996b) \\
\hline $\begin{array}{l}\text { Permits strategy explanation, adaptation and } \\
\text { communication throughout the organization }\end{array}$ & Kaplan and Norton (1996b) \\
\hline
\end{tabular}


End of Table 4

\begin{tabular}{ll}
\hline Advantages & Authors in literature \\
\hline $\begin{array}{l}\text { Consents individual goals alignment with } \\
\text { organizational strategy }\end{array}$ & Kaplan and Norton (1996b) \\
\hline $\begin{array}{l}\text { Provides useful feedback for organizational } \\
\text { learning and performance development }\end{array}$ & Malina and Selto (2001) \\
\hline Favors pro-activeness over reaction & Bourguignon et al. (2004) \\
\hline Focuses on clients and markets & Kanji and Moura de Sá (2002) \\
\hline $\begin{array}{l}\text { Connects top management decisions to lower levels } \\
\text { activities }\end{array}$ & Bourguignon et al. (2004) \\
\hline
\end{tabular}

Table 5. BSC Disadvantages

\begin{tabular}{ll}
\hline Disadvantages & Authors in literature \\
\hline $\begin{array}{l}\text { The BSC is not designed to communicate } \\
\text { strategy to the lowers levels of the organization } \\
\text { but to do address top and middle management }\end{array}$ & Speckbacher et al. (2003) \\
\hline High costs in implementing the BSC & Fu et al. (2008); Ittner and Larcker (1998) \\
\hline Focus on clients overlooking other stakeholders & Kaiji and Sá (2002) \\
\hline $\begin{array}{l}\text { Difficulties in estimating cause and effect } \\
\text { relationships regarding some variables }\end{array}$ & $\begin{array}{l}\text { Nørreklit (2003); Kanji and Moura e Sá } \\
\text { (2002) }\end{array}$ \\
\hline The BSC is a complex system & $\begin{array}{l}\text { Ittner and Larcker (1998); Drew and Kaye } \\
\text { (2007) }\end{array}$ \\
\hline Takes too much time to design and implement & Drew and Kaye (2007) \\
\hline
\end{tabular}

Theory provides conflicting predictions as to whether the BSC presents more advantages or disadvantages in its adoption and implementation. Even if plain support for the complexity in estimating the result of related benefits over related costs exists in literature, in practice the BSC is a more and more commonly used tool.

\section{Reported evidence on the use of the BSC}

Literature on the use of the BSC presents evidence from several locations and international studies (Nørreklit 2003; Speckbacher et al. 2003; Malina and Salto 2001) as this management control system's usage presents fast dissemination in the world (Ax and Bjørnenak 2005). Authors report the use of the BSC in $40 \%$ of firms listed in the Fortune 500 (Williams 2001), and in $20 \%$ of firms in a study covering 600 financial services firms in the United States (Ittner et al. 2003). In Europe, Kald and Nilsson (2000) study accounts for the use of the BSC in $27 \%$ of Swedish largest firms adding to $61 \%$ of those expecting to implement the system shortly (two years). Speckbacher et al. (2003) report the findings of a study addressing firms in Germany, Switzerland and Austria presenting the overall BSC usage rate is of $25 \%$. Regarding the Middle-East, 
Juhmani (2007) finds evidence of the use of BSC on $45 \%$ of firms covered in a study in Bahrain. In India Anand et al. (2005) report 53\% of large firms use the BSC. Extent evidence of the BSC usage around the globe reveals how adaptable and applicable the system is, demonstrating to be a flexible and useful tool.

Apart from the four main areas prescribed by Kaplan and Norton (1992) other authors suggest the use of different ones, according to the industry or the organizational context in question (Bourguignon et al. 2004; Veen-Dirks and Wijn 2002; Epstein and Manzoni 1998). Social performance indicators may be added to the BSC (Chatterji and Levine 2006) as well as corporative social responsibility ones Lusk et al. (2006) and corporate citizenship (Malina and Selto 2001) enabling stakeholders to have a wider view of the firm's performance. Ax and Bjørnenak (2005) describe the way Swedish firms enlarged the BSC by adding a group of indicators devoted to employees and Speckbacher et al. (2003) report the use of indicators related to suppliers and environmental dimensions.

The number of indicators used in the BSC impacts on the utility of the instrument, since the high number of indicators generates lower effectiveness of the system (Ittner and Larcker 1998) even if some organizations keep on using far more than advisable (Lipe and Salterio 2002). An adequate number of indicators are necessary to avoid superfluous information (Bourguignon et al. 2004), in order to respect the human cognitive system and administrative simplicity (Malina and Selto 2001). The correct usage of the BSC permits the supply of permanent inflows of pertinent information to supply managers with a powerful help in the decision making process. The regular use of this management control system (Jurkštienè et al. 2008) enables top management to have a constant picture of how strategy is implemented, allowing for the necessary adjustments to take place Kaplan and Norton 1996b; Malina and Selto 2001; Walker and Ainsworth 2007) and consequent organizational learning (Wong-On-Wing et al. 2007). The use of strategy maps (Kaplan and Norton 2004) may facilitate organizational learning namely through the relationships established between different kinds of indicators (Neely and $\mathrm{Al}$ Najjar 2006). According to Kaplan and Norton (2000) the BSC is an instrument serving strategic and cultural change.

\section{Research approach}

The conflicting theory and evidence discussed above does not allow formulating definitive predictions even at a general level as to what level of BSC usage to expect in Madeira Island largest firms. Literature provides no indication of whether the use of BSC in Madeira Island should differ from previous studied in other locations. Furthermore, no prior theory or evidence allows making predictions to whether the BSC indicators used in Madeira Island largest firms should be different from those used in firms from other regions. This article presents the findings of a descriptive and exploratory study aiming to provide answers to the following research questions:

Research question \# 1 - Who conducts strategic management in Madeira Island largest firms?

Research question \# 2 - What kind of management control systems managers use in Madeira Island largest firms? 
Research question \# 3 - Among Madeira Island largest firms, which ones apply the BSC?

Research question \# 4 - What are the reasons for managers not to use the BSC among Madeira Island largest firms? When not applying the system at the present, are managers considering a future introduction of the BSC in Madeira Island largest firms?

Research question \# 5 - What kind of indicators managers use in Madeira Island largest firms' management control systems? Which ones?

Research question \# 6 - Which are the reasons managers present to their choice of adopted indicators?

\section{Method}

This study addresses the present state of the BSC usage among Madeira Island largest firms, based upon the top national firms among the published ranks (top 500 and top 1000 firms) from the 3 highest standard Portuguese daily and weekly newspapers. The research addresses the largest firms in the Island since evidence supports size to be a driver for the emergence and use of management control systems (Davila 2005; Gumbus and Lussier 2006). Following Bisbe and Otley (2004) in their study in Spain, this research considers for location criteria purposes the head office's address. From all listed firms the ones presenting their in headquarters in Madeira Island are a total of 163. The study addresses large firms, following Speckbacher et al. (2003), Kaplan and Norton (1996a) and Hoque and James (2000), when considering that large firms present the highest BSC implementation levels. Sending the questionnaires to all of the 163 largest firms in Madeira Island allowed for an enough homogenous collection of firms expected to use some kind of management control system, within geographical reach and likely to collaborate with the study.

The survey combines qualitative and quantitative information on how the firms formalize practices to develop management control systems, which tool do they have in use and the most relevant indicators employed. This study provides a profound analysis of the present state of BSC implementation in Madeira Island largest firms, to a detail not previously found in literature. The empirical setting's relative small dimension allowed for an in-depth study on the characterization of firms involved, the type of indicators used and the justifications for the use of BSC, such as its advantages. Some of previous studies, for example, covered companies recommended by consulting companies (Malmi 2001), other studies have insufficient feed-back (Hoque and James 2000; Rigby 2001) or only estimate findings (Silk 1998; Paulsen 2001; Marr 2001; Williams 2001). The study by Speckbacher et al. (2003) presents a similar approach to the implementation of BSC in German-speaking countries, allowing for some comparison in terms of results and conclusions.

\section{Research data}

In a first step, the departments of management control/strategic planning of the companies were contacted by telephone to find out the most competent person for answering a questionnaire on the BSC as in Henri (2006), Widener (2006) and Hoque (2005). The 
postal survey was sent to all 163 firms asking for returning questionnaires within 4 weeks, similar to Bisbe and Otley (2004) and Hoque (2005). The accompanying letter guaranteed confidentiality and exclusive scientific use of data as in Juhmani (2007). Two follow-ups to non-respondents were used (one phone call and one e-mail message) in order to raise the response rate. 31 of the 163 sent questionnaires were received back, 30 valid ones were used $(19 \%)$. While relatively low, this level of response rate was expected because of the length and complexity of the questionnaires. Nevertheless, the response rate is within expected values - similarly to Henri (2006) 24\%, Widener (2006) $14 \%$, Ittner et al. (2003) $23.3 \%$, or Hall (2008) $22.3 \%$. Analysing firm characteristics on the archival data (assets, sales, and employment) across respondents vs. non-respondents did not reveal any systematic non-response biases. The respondents' profile is on average 40 years old, working in the firm for 13 years, 11 of them in the present position. On the majority of cases (73\%) is a male and manager $-73 \%$ of respondents are board members, $27 \%$ of respondents are executives from the department of management control.

For classification purposes we've adopted the criteria on the databases, taking into account the specific business context in Madeira Island. Following those criteria small firms have less than 7.000.000.00 euros on total annual sales and fewer than 50 employees; large firms present more than 40.000.000.00 euros on total annual sales and are larger than 250 employees and medium firms are the ones presenting figures in between these two extremes. Considering the firms participating in this study, they come from several industries (Table 6), presenting high sales volume (average 50.000.000.00 euros) and medium number of employees (average 119).

Considering the person in charge of top management and who is responsible for defining strategic management decision making among the firms in the study, in the majority of cases this person is the entrepreneur or the business owner (see Table 7). Regarding the management control system the firms in the study use, the BSC is the less common and the Tableaux de Bord the most used one (see Table 8).

Table 6. Firms' industry and dimension

\begin{tabular}{lllll}
\hline Firms & Small & Medium & Large & Total \\
\hline Tourism & $3.3 \%$ & $3.3 \%$ & $3.3 \%$ & $9.9 \%$ \\
\hline Transports and logistics & - & $10 \%$ & $10 \%$ & $20 \%$ \\
\hline Energy & - & $3.3 \%$ & - & $3.3 \%$ \\
\hline Trading & $6.7 \%$ & $10 \%$ & $6.7 \%$ & $23.4 \%$ \\
\hline Manufacturing & $6.7 \%$ & - & $6.7 \%$ & $13.4 \%$ \\
\hline Construction works & - & $6.7 \%$ & - & $6.7 \%$ \\
\hline Services & $3.3 \%$ & - & $10 \%$ & $13.3 \%$ \\
\hline Other & $10 \%$ & - & - & $10 \%$ \\
\hline Total & $30 \%$ & $33.3 \%$ & $36.7 \%$ & $100 \%$ \\
\hline
\end{tabular}


Table 7. Top management responsibility and strategic management decision making

\begin{tabular}{lll}
\hline Key person & $\begin{array}{l}\text { Top management } \\
\text { responsibility }\end{array}$ & $\begin{array}{l}\text { Strategic management } \\
\text { decision making }\end{array}$ \\
\hline Entrepreneur / business owner & $70 \%$ & $70 \%$ \\
\hline Managers & $7 \%$ & $3 \%$ \\
\hline Both & $13 \%$ & $17 \%$ \\
\hline Other & $10 \%$ & $10 \%$ \\
\hline Total & $100 \%$ & $100 \%$ \\
\hline
\end{tabular}

Table 8. Management control system in use

\begin{tabular}{ll}
\hline Tableaux de Bord & $23 \%$ \\
\hline Balanced Scorecard & $10 \%$ \\
\hline Other & $20 \%$ \\
\hline None & $47 \%$ \\
\hline Total & $100 \%$ \\
\hline
\end{tabular}

BSC users come from tourism, manufacturing and energy industries, $67 \%$ is over 250 employees, top management and strategic management decision making is entirely in hands of the entrepreneur/business owner and strategic evaluation takes place once a year in $67 \%$ of them. Firms that employ the BSC justify that use for different reasons (see Table 9) and present the associated benefits of utilizing this particular management control system (see Table 10). The majority of firms covered in this study do not use the BSC and respondent presented their reasons why (see Table 11).

Table 9. Justification for BSC use

\begin{tabular}{ll}
\hline Permitting a global view of the firm & $100 \%$ \\
\hline Being the more common system & $33 \%$ \\
\hline Allowing strategy communication to the all of the firm & $67 \%$ \\
\hline Permitting to align personal and departmental goals to strategy & $100 \%$ \\
\hline Allowing for strategic learning & $100 \%$ \\
\hline Permitting strategy improvement & $100 \%$ \\
\hline
\end{tabular}

Table 10. BSC Benefits

\begin{tabular}{ll}
\hline Financial Performance & $100 \%$ \\
\hline Internal communication & $100 \%$ \\
\hline Strategic learning & $67 \%$ \\
\hline Appraisal and reward systems & $0 \%$ \\
\hline
\end{tabular}


Table 11. Justification for not using the BSC

\begin{tabular}{ll}
\hline BSC cost / effect ratio & $26 \%$ \\
\hline BSC implementation difficulties & $19 \%$ \\
\hline Not knowing the BSC & $19 \%$ \\
\hline Other & $41 \%$ \\
\hline
\end{tabular}

Firms using the Tableaux de Bord are mainly small and medium size (57\%) and primarily come from the transport and logistics industry (57\%). Top management and strategic management decision making is in hands of the entrepreneur/business owner in about $80 \%$ of cases and strategic evaluation takes place continuously over the year in $57 \%$ of firms. The majority of firms using the Tableaux de Bord plan on adopting the BSC soon (3.5 years on average); still $43 \%$ of firms do not consider adopting the BSC in the future.

The majority of respondents doesn't apply the BSC in their firms but still use a set of indicators to guide them in their decision making process and strategic management. The use of financial indicators alone seam negatively correlated to firm size; $56 \%$ of small firms opted for adopting only financial indicators whereas only $9 \%$ of large firms did that. On the contrary, the use of both financial and non financial indicators seam to be positively correlated to firm size; $91 \%$ of large firms opted for adopting both indicators whereas only $33 \%$ of small firms did so.

Considering all the firms responses, the majority (67\%) adopts both financial and non financial indicators (see Table 12). Firms just using financial indicators are mainly small and medium size $(89 \%)$ and more commonly come from the trading industry (44\%). In these firms, top management and strategic management decision making is entirely up to the entrepreneur/business owner and strategic evaluation takes place once a year in $67 \%$ of them.

Regarding firms that use non financial indicators, only $52.4 \%$ of them are small and medium size, coming from different industries (tourism - 14.3\%, transports and logistics $-28.7 \%$; energy $-4.7 \%$; trading $-14.3 \%$; manufacturing $-9.5 \%$; construction works $-9.5 \%$; services $-19 \%$ ). In these firms top management and strategic management decision making is in hands of the entrepreneur/business owner in about $73.8 \%$ of cases and strategic evaluation takes place once a year in $52.4 \%$ of firms. Managers that employ non financial indicators justify their use for different reasons (see Table 13).

Respondents presented examples of leading indicators in use from the three BSC non financial areas - clients, internal processes, and learning and growth (see Table 14).

Table 12. Types of indicators used and firm size

\begin{tabular}{lllll}
\hline Firms/Indicators & Small & Medium & Large & All firms \\
\hline Only financial indicators & $56 \%$ & $30 \%$ & $9 \%$ & $30 \%$ \\
\hline Only non financial indicators & $11 \%$ & - & - & $3 \%$ \\
\hline Both financial and non financial indicators & $33 \%$ & $70 \%$ & $91 \%$ & $67 \%$ \\
\hline Total & $100 \%$ & $100 \%$ & $100 \%$ & $100 \%$ \\
\hline
\end{tabular}


Table 13. Justification for using non financial indicators

The firm is best evaluated based on indicators that reveal its medium/long term survival probabilities

Competition is getting stronger so it is necessary to have non traditional indicators to face it

$67 \%$

Financial indicators only give historic short term information $24 \%$

Table 14. Non financial dimensions

\begin{tabular}{ll}
\hline Consumer satisfaction & $86 \%$ \\
\hline Product's quality & $71 \%$ \\
\hline Internal efficiency & $71 \%$ \\
\hline Human resources motivation & $52 \%$ \\
\hline Market share & $29 \%$ \\
\hline Technological capability & $19 \%$ \\
\hline Innovation & $14 \%$ \\
\hline Other & $19 \%$ \\
\hline
\end{tabular}

\section{Discussion and conclusions}

The study provides systematic original evidence on the application of the BSC concept in Madeira Island largest firms. Considering that firms participating in this study are among the largest ones in Madeira Island, present high sales volume (average 50.000 .000 .00 euros) and medium number of employees (average 119). A paradox arises since data regarding the key person in charge of top management and responsible for defining strategic management decision making among the firms in the study is in most cases the entrepreneur or the business owner. Such facts are inconsistent with the characteristics of large organizations; in fact, they match the profile of small organizations, which usually present simpler structures (low departmentalisation, wide spans of control, centralized authority and little formalization) and less necessity for sophisticated control systems.

The study shows that only a minority of firms (10\%) use the BSC. This figure is far from the US reported rates (Williams 2001; Ittner et al. 2003), or the numbers from European studies (Kald and Nilsson 2000; Speckbacher et al. 2003) and even more distinct from the empirical data collected in India (Anand et al. 2005) and in the Middle-East (Juhmani 2007). Regarding such low level of BSC usage, questions may arise concerning the size and geographical contingencies the Region in the study present; for Madeira Island is both a small island (306 square miles - 794 square $\mathrm{km}$ ) and it is also part of Europe's peripheral territories.

Respondents from firms adopting the BSC are unanimous when declaring that its use gives them a global view of the firm, allows for strategic learning and strategic im- 
provement and permits them to align personal and departmental goals to strategy. With respect to the expected benefits companies using BSC have, corporations in the study view $\mathrm{BSC}$ as a useful tool for enhancing financial performance, internal communication and strategic learning. On the other hand, BSC users do not report any use of this management control system in connection to the appraisal and reward systems as a result, none of the firms adopts a BSC-based reward system.

Respondents from corporations not adopting the BSC present several issues that keep them from applying this management control system, like being too expensive for the created benefits (cost/effect ratio), being too difficult to implement, or simply not knowing the tool at all. According to collected data, almost a quarter of largest firms in the study use the Tableaux de Bord as their management control system. They come primarily come from the transport and logistics industry. Contrary to BSC users, the majority these firms to run strategic evaluation continuously and not just once a year. The majority of firms using the Tableaux de Bord plan on adopting the BSC soon (3.5 years on average), but still $43 \%$ of them do not consider adopting the BSC in the future.

However, firms in the study explore the potentiality of indicators' use to the full, since the majority of them (67\%) use both financial indicators and non financial indicators (the later ones coming from the three BSC non financial areas - clients, internal processes, and learning and growth). According to respondents, firms in Madeira Island use non financial indicators mainly because they are the best ones for evaluation purposes (revealing medium/long term survival probabilities) and since competition is getting stronger, they believe the system provides information coming from helpful non traditional indicators.

Most non financial indicators in use in Madeira Island largest firms come from four main dimensions; consumer's satisfaction, product's quality, internal efficiency and human resources motivation. This means, respondents report the use of leading indicators from the three BSC non financial areas - clients, internal processes, and learning and growth. According to data collected, firms in the study seam to value non financial indicators across the different categories, even if not in similar degrees; respondents rate clients' indicators higher, followed by internal processes ones, valuing less the learning and growth ones. Collected evidence is consistent with the rationale of the BSC running, based upon a cause and effect relationship between the different sets of indicators. Learning and growth indicators are expected to have impact on internal processes ones, and these will influence clients' indicators. In the end of this cause and effect chain the financial indicators will reflect the overall result of firm activity. Even if the majority of firms in the study do not recognise they are formally adopting the BSC, respondents seam to describe their use of sets of indicators in the true spirit of the BSC. If the study accounted for this informal use of the BSC, reported adoption rate would be far more relevant. This research presents managerial implications regarding the indicators in management control systems Madeira Island largest firms' use. 


\section{Limitations and future research}

This research work is subjected to several potential limitations, some relate to the method used and others regarding the empirical setting. Due to the study's cross-sectional essence, fully comprehending the dynamics that drove each firm to the current state regarding management control systems is not possible. The study uses the survey method for collecting data presenting a low response rate, even if expected and following average values in similar studies. The use of postal surveys does not allow the researcher to elucidate respondents along their questionnaire answering if they have any doubts. Considering the research's scenery - the small and peripheral Madeira Island - limited the number and diversity of large firms involved in the study. Even though a large number of respondents do not admit to use of a management control system, they do employ sets of indicators to assist them in the decision making process even if not formally adopted. If such informal use of a system close to the BSC was considered in the study results on the usage of the BSC in Madeira Island largest firms might have been considerably different.

The results of this study provide guidance for future research to be conducted in several other locations in order to cumulative build a body of knowledge on the BSC usage across different regions and industries. Studies in other Europe's peripheral territories to compare against this study's results are welcome. The present work can be further extended through the development of confirmatory quantitative work to follow this exploratory qualitative and descriptive research, such as testing for industry or size effects on the BSC adoption and indicators choice. Since the use of financial indicators alone seem negatively correlated to firm size, future confirmatory research should test such hypothesis. On the contrary, given that the use of both financial and non financial indicators seem to be positively correlated to firm size, further work could equally test the suggested correlation.

Additional qualitative research can also be engaged using longitudinal studies to assess BSC adoption and implementation process related variables, like sequential steps adoption, leading key person in the firm, indicators choice criteria or organizational routines development to support the management control system. Additions to this research could explore the internal characteristics that might influence the BSC usage, such as leadership style, organizational design or formalization level. Further extensions of this exploratory work can drive researchers into analysing contextual variables like competitive dynamics issues or cultural aspects.

\section{References}

Anand, M.; Sahay, B. S.; Saha, S. 2005. Balanced scorecard in Indian companies, Vikalpa 30(2): $11-25$.

Ax, C.; Bjørnenak, T. 2005. Bundling and diffusion of management accounting innovations the case of the balanced scorecard in Sweden, Management Accounting Research 16(1): 1-20. doi:10.1016/j.mar.2004.12.002

Bisbe, J.; Otley, D. 2004. The effects of the interactive use of management control systems on product innovation, Accounting, Organizations and Society 29(8): 709-737.

doi:10.1016/j.aos.2003.10.010 
Bourguignon, A.; Malleret, V.; Nørreklit, H. 2004. The American balanced scorecard versus the French tableau de bord: the ideological dimension, Management Accounting Research 15(2): 107-134. doi:10.1016/j.mar.2003.12.006

Cadez, S.; Guilding, C. 2008. An exploratory investigation of an integrated contingency model of strategic management accounting, Accounting, Organizations and Society 33(7-8): 836-863. doi:10.1016/j.aos.2008.01.003

Chatterji, A.; Levine, D. I. 2006. Breaking down the wall of codes: evaluating no-financial performance measurement, California Management Review 48(2): 29-51.

Collis, D. J.; Rukstad, M. G. 2008. Can you say what your strategy is? Harvard Business Review 86(4): 82-90.

Davila, T. 2005. An exploratory study on the emergence of management control systems: formalizing human resources in small growing firms, Accounting, Organizations and Society 30(3): 223-248. doi:10.1016/j.aos.2004.05.006

DeBusk, G. K.; Brown, R. M.; Killough, L. N. 2003. Components and relative weights in utilization of dashboard measurement systems like the Balanced Scorecard, The British Accounting Review 35(3): 215-231. doi:10.1016/S0890-8389(03)00026-X

Drew, S. A.; Kaye, R. 2007. Engaging boards in corporate direction-setting: strategic scorecards, European Management Journal 25(5): 359-369. doi:10.1016/j.emj.2007.07.006

Epstein, M.; Manzoni, J.-F. 1998. Implementing corporate strategy: from tableuax de bord to Balanced Scorecard, European Management Journal 16(2): 190-203.

doi:10.1016/S0263-2373(97)00087-X

Fu, C.-J.; Chang, B.-G.; Chen, S. K. 2008. Effectiveness of combining bonus plan and balanced scorecard, Northeast Decision Sciences Institute Proceedings March: 28-30.

Gumbus, A.; Lussier, R. N. 2006. Entrepreneurs use a Balanced Scorecard to translate strategy into performance measures, Journal of Small Business Management 44(3): 407-425. doi:10.1111/ j.1540-627X.2006.00179.x

Hall, M. 2008. The effect of comprehensive performance measurement systems on role clarity, psychological empowerment and managerial performance, Accounting, Organizations and Society 33(2-3): 141-163. doi:10.1016/j.aos.2007.02.004

Henri, J.-F. 2006. Management control systems and strategy: A resource-based perspective, Accounting, Organizations and Society 31(6): 529-558. doi:10.1016/j.aos.2005.07.001

Hoque, Z. 2005. Linking environmental uncertainty to non-financial performance measures and performance: a research note, The British Accounting Review 37(4): 471-481.

doi:10.1016/j.bar.2005.08.003

Hoque, Z.; James, W. 2000. Linking Balanced Scorecard measures to size and market factors: Impact on organizational performance, Journal of Management Accounting Research (12): 1-17.

Islam, M.; Kellermanns, F. 2006. Firm and individual - Level determinants of Balanced Scorecard usage, Canadian Accounting Perspectives 5(2): 181-207.

doi:10.1506/74LJ-CMWM-FUAD-NMUT

Ittner, C.; Larcker, D. 1998. Innovations in performance measurement: Trends and research implications, Journal of Management Accounting Research (10): 205-238.

Ittner, C. D.; Larcker, D. F.; Randall, T. 2003. Performance implications of strategic performance measurement in financial services firms, Accounting, Organizations and Society 28(7-8): 715-741. doi:10.1016/S0361-3682(03)00033-3

Ittner, C. D. 2008. Does measuring intangibles for management purposes improve performance? A review of the evidence, Accounting and Business Research 38(3): 261-272. 
Juhmani, O. I. M. 2007. Usage, motives and usefulness of the Balanced Scorecard: Evidence from Bahrain, International Journal of Business Research 7(5): 106-117.

Jurkštienè, A.; Darškuvienè, V.; Dūda, A. 2008. Management control systems and stakeholders' interests in Lithuanian multinational companies: Cases from the telecommunications industry, Journal of Business Economics and Management 9(2): 97-106.

doi:10.3846/1611-1699.2008.9.97-106

Kald, M.; Nilsson, F. 2000. Performance measurement at Nordic companies, European Management Journal 18(1): 113-127. doi:10.1016/S0263-2373(99)00074-2

Kanji, G. K.; Moura e Sá, P. 2002. Kanji’s Business Scorecard, Total Quality Management \& Business Excellence 13(1): 13-27. doi:10.1080/09544120120098537

Kaplan, R. S.; Norton, D. P. 1992. The Balanced Scorecard: Measures that drive performance, Harvard Business Review 70(1): 71-79.

Kaplan, R. S.; Norton, D. P. 1996a. Using the Balanced Scorecard as a strategic management system, Harvard Business Review 74(1): 75-85.

Kaplan, R.; Norton, D. 1996b. Translating strategy into action - The Balanced Scorecard. Harvard Business School Press, Boston: Massachusetts.

Kaplan, R.; Norton, D. 2000. Having trouble with your strategy? Then Map It, Harvard Business Review September-October, 167-176.

Kaplan, R.; Norton, D. 2004. Strategy Maps - converting intangible assets into tangible outcomes. Boston: Harvard Business School Publishing Corporation.

Kaplan, R. S.; Norton, D. P. 2005. The office of strategy management, Harvard Business Review 83(10): 72-80.

Kaplan, R. S.; Norton, D. P. 2008. Mastering the management system, Harvard Business Review 86(1): 63-77.

Kumpikaite, V. 2008. Human resource development in learning organization, Journal of Business Economics and Management 9(1): 25-31. doi:10.3846/1611-1699.2008.9.25-31

Lipe, M. G.; Salterio, S. E. 2000. The Balanced Scorecard: Judgmental effects off common and unique performance measures, The Accounting Review 75(3): 283-298.

doi:10.2308/accr.2000.75.3.283

Lipe, M. G.; Salterio, S. 2002. A note on the judgmental effects of the balanced scorecard's information organization, Accounting, Organizations and Society 27(6): 531-540.

doi:10.1016/S0361-3682(01)00059-9

Lobanova, L. 2009. Žmogiškujų išteklių vadybos verte žiniomis grindžiamoje visuomenèje [Human resources management value in knowledge-based society], Verslas: teorija ir praktika [Business: Theory and Practice] 10(3): 233-246. (in Lithuanian).

doi:10.3846/1648-0627.2009.10.233-246

Lusk, E. J.; Halperin, M. Y.; Zhang, B. D. 2006. The Balanced Scorecard: suggestions for rebalancing, Problems and Perspectives in Management 4(2): 100-114.

Malina, M. A.; Selto, F. H. 2001. Communicating and controlling strategy: an empirical study of the effectiveness of the Balanced Scorecard, Journal of Management Accounting Research 13(1): 47-90. doi:10.2308/jmar.2001.13.1.47

Malmi, T. 2001. Balanced Scorecards in Finnish companies: a research note, Management Accounting Research 12(2): 207-220. doi:10.1006/mare.2000.0154

Marr, B. 2001. Scored for life [Balanced Scorecard], Financial Management April: 30.

Mooraj, S.; Oyon, D.; Hostettler, D. 1999. The Balanced Scorecard: a Necessary Good or an 
Unnecessary Evil? European Management Journal 17(5): 481-491.

doi:10.1016/S0263-2373(99)00034-1

Neely, A.; Al Najjar, M. 2006. Management learning not management control: the true role of performance measurement, California Management Review 48(3): 101-114.

Nørreklit, H. 2000. The balance on the Balanced Scorecard a critical analysis of some of its assumptions, Management Accounting Research 11(1): 65-88. doi:10.1006/mare.1999.0121

Nørreklit, H. 2003. The Balanced Scorecard: what is the score? Rhetorical analysis of the Balanced Scorecard, Accounting, Organizations and Society 28(6): 591-619.

doi:10.1016/S0361-3682(02)00097-1

Paulsen, K. 2001. Bringing the score up by taking it down, Agency Sales 31(9): 15-17.

Pun, K. F.; White, A. S. 2005. A performance measurement paradigm for integrating strategy formulation: A review of systems and frameworks systems and frameworks, International Journal of Management Reviews 7(1): 49-71. doi:10.1111/j.1468-2370.2005.00106.x

Rigby, D. 2001. Management tools and techniques: a survey, California Management Review 43(2): 139-160.

Silk, S. 1998. Automating the Balanced Scorecard, Management Accounting 79(11): 38-44.

Sioncke, G.; Parmentier A. 2007. Different approaches to strategy formulation, Total Quality Management \& Business Excellence 18(1-2): 181-187. doi:10.1080/14783360601053350

Sliwka, D. 2002. On the use of non financial performance measures in management compensation, Journal of Economics \& Management Strategy 11(3): 487-511.

doi:10.1111/j.1430-9134.2002.00487.x

Speckbacher, G.; Bischof, J.; Pfeiffer, T. 2003. A descriptive analysis on the implementation of Balanced Scorecards in German-speaking countries, Management Accounting Research 14(4): 361-387. doi:10.1016/j.mar.2003.10.001

Thompson, K.; Mathys, N. 2008. The aligned balanced scorecard: a improved tool for building high performance organizations, Organizational Dynamics 37(4): 378-393.

doi:10.1016/j.orgdyn.2008.07.006

Valentinavičius, S. 2009. Theoretical aspects of enterprise business strategy formation, Business: Theory and Practice 10(2): 130-141. doi:10.3846/1648-0627.2009.10.130-141

Veen-Dirks, P.; Wijn, M. 2002. Strategic control: meshing critical success factors with the Balanced Scorecard, Long Range Planning 35(4): 407-427. doi:10.1016/S0024-6301(02)00066-3

Walker, K. B.; Ainsworth, P. L. 2007. Achieving competitive advantage in departments of accounting: Management principles and the balanced scorecard, Accounting and Financial Studies Journal 11(1): 65-82.

Widener, S. K. 2006. Associations between strategic resource importance and performance measure use: The impact on firm performance, Management Accounting Research 17: 433-457. doi:10.1016/j.mar.2005.10.002

Wiersma, E. 2008. An exploratory study of relative and incremental information content of two non-financial performance measures: Field study evidence on absence frequency and on-time delivery, Accounting, Organizations and Society 33(2-3): 249-265. doi:10.1016/j.aos.2006.12.004 Williams, S. 2001. Drive your business forward with the Balanced Scorecard, Management Services 45(6): 28-30.

Wong-On-Wing, B.; Guo, L.; Wei, L.; Yang, D. 2007. Reducing conflict in balanced scorecard evaluations, Accounting, Organizations and Society 32(4-5): 363 - 377.

doi:10.1016/j.aos.2006.05.001 


\title{
VALDYMO SISTEMA MADEIROS SALOS DIDŽIOSIOSE IMONĖSE: REZULTATŲ APSKAITOS SISTEMOS NAUDOJIMO PAVYZDŽIU
}

\author{
C. Curado, J. Manica
}

Santrauka

Straipsnyje pateikiami duomenys apie mokslinį valdymo kontrolès sistemų tyrimą, atliktą Madeiros saloje naudojant subalansuotos apskaitos duomenis. Surinkti empiriniai duomenys rodo naudojimąsi subalansuotos apskaitos modeliu didžiausiose salos korporacijose ir pateikia atsakymus į tyrimo klausimus. Tyrimo duomenys atskleidžia svarbius skirtumus tarp valdymo kontrolès sistemų naudojimo įvairiose i̇monėse, lyginant kitu regionų ankstesnių tyrimų ataskaitas. Šiame tyrime aptariama organizaciju vadybos reikšmė, kviečiama aptarti būsimų mokslinių tyrimų kryptis.

Reikšminiai žodžiai: valdymo sistemos, darni apskaita, didelès įmonès, empirinis tyrimas.

Carla CURADO. Ph. D, is at present a professor at the Management Department at ISEG - Economics and Business School - Technical University of Lisbon. Her most recent scientific publications involve knowledge management intellectual capital, the knowledge based-view of the firm, organizational learning and organizational design. Research on the BSC is very interesting due to the proximity to measuring organizational intangibles, and tracing organizational knowledge and learning.

José MANICA completed his master degree by developing empirical research on the BSC usage among large corporations in his home land: the Madeira Island. This student presents full potential to extend his research capabilities and progress further. 